\title{
KARAKTERISTIK HABITAT KEPITING BAKAU (Scylla spp) DI PERAIRAN PANTAI DESA TODOWONGI KECAMATAN JAILOLO SELATAN KABUPATEN HALMAHERA BARAT
}

\author{
Rugaya Serosero \\ Staf Pengajar FPIK UNKHAIR-Ternate, $\boldsymbol{e}$-mail: -
}

\begin{abstract}
ABSTRAK
Penelitian yang dilakukan di perairan pantai Desa Todowongi ini bertujuan untuk mengetahui karakteristik habitat kepiting bakau dengan menentukan tekstur substrat dan mengetahui kualitas perairan yang menjadi habitat kepiting bakau serta makanan alami khususnya makrozoobentos di daerah hutan mangrove Desa Todowongi. Hasil penelitian menunjukkan bahwa tekstur substrat adalah lempung berlumpur. Parameter lingkungan seperti suhu, salinitas dan pH air berada pada kondisi yang layak bagi kehidupan kepiting bakau. Makanan alami khususnya makrozoobentos yang ditemukan terdiri atas 10 jenis dengan kepadatan tertinggi pada jenis Turricula javana dan Tereblaria palustris $\left.\left(2,467 \mathrm{ind} / \mathrm{m}^{2}\right)\right)$, keanekaragamannya tergolong rendah dan tidak ada jenis yang mendominasi.
\end{abstract}

\section{Kata Kunci: Kepiting bakau, karakteristik, habitat, desa Todowangi}

\section{PENDAHULUAN}

\subsection{Latar Belakang}

Hutan mangrove merupakan sumberdaya perairan yang memiliki karakteristik yang khas dan memiliki fungsi ekologis dan ekonomis. Secara ekologis, hutan mangrove berfungsi sebagai daerah pemijahan dan pembesaran (nursery ground) berbagai spesies komersial baik ikan maupun udang, kepiting serta habitat berbagai jenis fauna seperti burung, ular dan lainlain.

Kepiting bakau adalah salah satu sumberdaya perikanan yang menjadikan hutan mangrove sebagai habitatnya. Potensinya di Indonesia cukup besar, karena kepiting memiliki distribusi yang luas dan dapat ditemukan hampir di seluruh perairan Indonesia terutama pada perairan yang ditumbuhi hutan mangrove. Perairan pantai Kabupaten Halmahera Barat khususnya Desa Todowongi juga merupakan salah satu daerah yang memiliki potensi kepiting bakau yang tinggi. Hutan mangrove sebagai habitat dari kepiting bakau ini telah banyak dimanfaatkan oleh masyarakat sebagai kayu bakar dan keperluan rumah tangga lainnya. Eksploitasi kepiting bakau juga sudah mulai dilakukan untuk dijual. Eksploitasi yang terus menerus dikhwatirkan akan mengancam keberadaan kepiting bakau di alam.
Seiring dengan meningkatkan pemahaman masyarakat tentang nilai gizi kepiting bakau sebagai salah satu sumberdaya perairan yang dapat dimakan selain ikan dan semakin tinggi permintaan pangsa pasar maka perlu dilakukan upaya untuk terus melestatrrikan sumberdaya tersebut. Kegiatan budidaya kepiting bakau merupakan salah satu alternatifnya. Oleh karena itu data dan informasi yang berkaitan dengan aspek-aspek budidaya antara lain karakteristik habitat kepiting bakau (Scylla spp) di habitat alaminya perlu disediakan. Penelitian ini dilakukan untuk mengkaji karakteristik habitat kepiting bakau di perairan pantai Desa Todowongi Kabupaten Halmahera Barat.

\subsection{Tujuan dan Manfaat Penelitian}

Penelitian ini dilakukan dengan tujuan untuk mengetahui karakteristik habitat kepiting bakau di Desa Todowongi Kecamatan Jailolo dengan menentukan tekstur substrat, mengetahui kualitas perairan dan mengetahui makanan alami (makrozoobentos) dan struktur komunitas makanan alami di daerah hutan mangrove yang menjadi habitat kepiting bakau Desa Todowongi.

Manfaat penelitian ini diharapkan dapat memberikan informasi tentang kualitas habitat kepiting bakau di alam sehingga dapat menjadi data dasar bagi kegiatan budidaya serta menjadi 
bahan pertimbangan bagi perlindungan, pengelolaan dan pemanfaatan sumberdaya kepiting bakau untuk masa yang akan datang.

\section{METODE PENELITIAN}

\subsection{Lokasi dan Waktu Penelitian}

Penelitian ini dilakukan di perairan hutan mangrove Desa Todowongi Kabupaten Halmahera Barat. Waktu pengambilan sampel pada akhir bulan April 2009. Sampel tanah hasil penelitian dianalisis di laboratorium Fisika dan Konservasi Tanah dan Air Fakultas Pertanian Universitas Sam Ratulangi Manado.

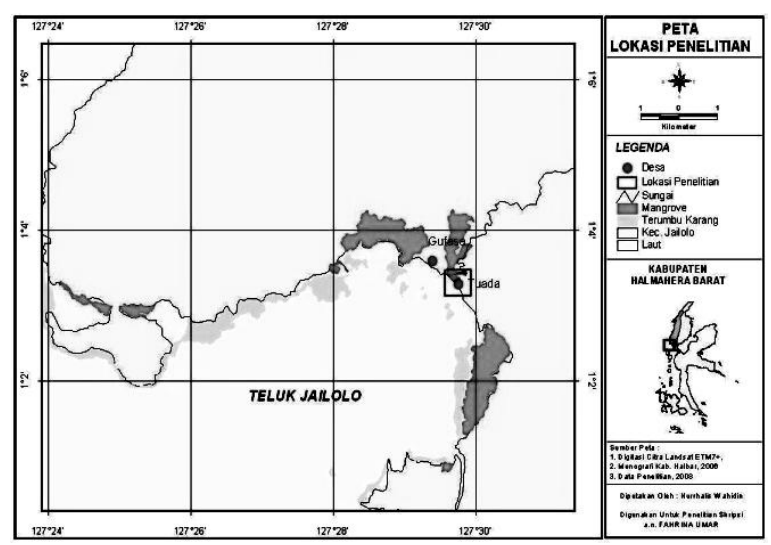

Gambar 1. Peta Lokasi Penelitian

\subsection{Alat dan Bahan}

Alat dan bahan yang digunakan terdiri atas alat pengukur kualitas air yaitu $\mathrm{pH}$ meter, hand refraktometer, termometer dan pipa paralon berdiameter 2,5 inchi untuk pengambilan sampel substrat. Untuk pengambilan sampel makrozoobentos digunakan kuadran 1 X 1 meter dan kantong plastik untuk menampung sampel.

\subsection{Metode Pengukuran}

\section{Penentuan Tekstur Substrat}

Pengambilan sampel sedimen dilakukan pada lokasi penangkapan kepiting bakau dengan 3 kali ulangan. Contoh sedimen dikumpulkan dengan menggunakan pipa paralon (PVC, diameter 2,5 inchi) dengan cara menancapkan pipa tersebut kepermukaan sedimen $(30 \mathrm{~cm})$. Pengambilan contoh sedimen sebanyak \pm 500 gram kemudian dimasukan ke dalam kantong plastik yang telah diberi label.Selanjutnya dibawa ke Laboratorium untuk dianalisis komposisi fraksinya untuk selanjutnya ditentukan tekstur substratnya.

\section{Kualitas Air}

Pengukuran kualitas air dilakukan untuk mengetahui kualitas habitat yang menjadi habitat kepiting bakau. Parameter kualitas air yang diukur meliputi suhu air, salinitas dan $\mathrm{pH}$ air. Pengukuran kualitas air dilakukan dengan pengulangan pengukuran 3 kali.

\section{Makanan Alami (Makrozoobentos)}

Pengamatan makanan alami kepiting bakau dikhususkan pada makrozoobentos. Pengambilan makrozoobentos dengan menggunakan kuadrat besi berukuran $1 \times 1$ meter. Sampel makrozoobentos juga diambil sesuai dengan lokasi penangkapan kepiting bakau. Pada lokasi pengamatan dipasang 3 buah lintasan dan setiap lintasan diletakan kuadran sebanyak 8 buah. Panjang lintasan disesuaikan dengan lebar hutan mangrove.

Sampel makrozoobentos yang ditemukan selanjutnya dimasukkan ke dalam kantong plastik yang telah diberi label sesuai kuadran dan lintasan. Selanjutnya dilakukan determinasi berdasarkan petunjuk Dharma (1989) dan Abbot (1989) untuk mengetahui jenisnya.

\subsection{Metode Analisis Data}

Tipe substrat kepiting bakau dilokasi penelitian ditentukan dengan menggunakan segitiga tekstur tanah. Data yang telah diperoleh dari hasil persentase keseluruhan ketiga fraksi (pasir, debu, dan liat) kemudian ditabulasikan dan disajikan dalam bentuk diagram segitiga tekstur untuk menentukan kelas tekstur tanah. Data hasil penentuan tekstur substrat dan pengukuran kualitas air dianalisis secara deksriptif.

Struktur Komunitas makanan alami (Makrozoobentos) ditentukan sebagai berikut :

A. Kepadatan Jenis (D) (Krebs, 1978 dalam Wattimury, 2006)

$$
D=\frac{\text { Total Individu Suatu Jenis }}{\text { Total Kotak Pengamatan }}
$$

\section{B. Keanekaragaman Jenis $(H)$}

Untuk mengetahui keanekaragaman jenis menggunakan indeks Shanon-Wiener (1949) dalam Ludwig dan Reynold (1988) sebagai berikut :

$$
H=-\sum_{i=1}^{s}\left[\frac{n i}{N}\right] \operatorname{Ln}\left[\frac{n i}{N}\right]
$$

Keterangan :

$\mathrm{H}=$ Indeks keanekaragaman jenis

$\mathrm{N}=$ Jumlah individu total (ind) 
$\mathrm{ni}=$ Jumlah sampel jenis ke-i (ind)

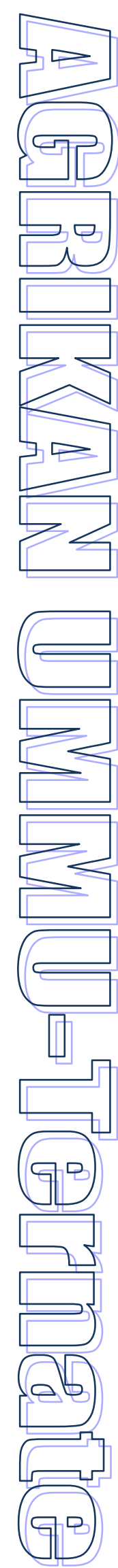

Kriteria : $\mathrm{H}^{\prime}<1=$ Keanekaragaman rendah

$1<\mathrm{H}^{\prime}<3,3=$ Keanekaragaman sedang

$\mathrm{H}^{\prime}<3,3=$ Keanekaragaman tinggi

\section{Indeks Dominasi (C) (Odum, 1986)}

$$
C^{\prime}=\sum\left(\frac{n i}{N}\right)^{2}
$$

Keterangan :

$C^{\prime}=$ Indeks Shimpson

ni = Jumlah individu sampel jenis ke-i

$\mathrm{N}=$ Jumlah individu seluruh jenis

Kriteria :

Nilai C' berkisar $0-1$

Jika C' mendekati 0 berarti tidak ada spesies yang mendominasi dan apabila nilai $C^{\prime}$ mendekati 1 berarti adanya salah satu spesies yang mendominasi.

\section{HASIL DAN PEMBAHASAN}

\subsection{Tekstur Substrat}

Dari hasil analisis tekstur terlihat bahwa fraksi pasir 66, 75\%, debu $23,10 \%$ dan liat $10,18 \%$. Fraksi pasir memiliki persentase tertinggi yaitu 40-87,5\%, kemudian fraksi debu $<50 \%$ dan selanjutnya fraksi liat yaitu $<20 \%$. Hal ini menunjukkan bahwa substrat di Desa Todowongi yang menjadi stasiun penelitian adalah lempung berpasir. Tekstur lempung berpasir adalah tanah yang bertekstur sedang tetapi agak kasar. Tanah bertekstur lempung akan mempunyai partikel-partikel yang mempunyai rasa ketiganya secara proporsional, apabila yang terasa lebih dominan adalah sifat pasir, maka berarti tanah bertekstur lempung berpasir (Hanafiah, 2005).

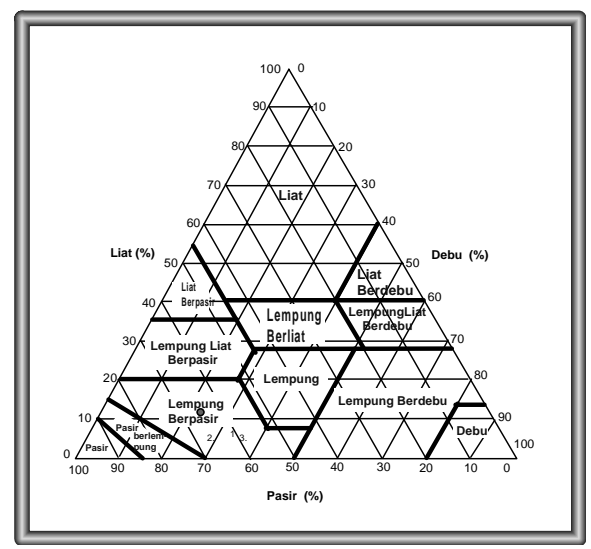

Gambar 2. Diagram segitiga tekstur tanah dan sebaran besar butir
Hasil analisis tekstur tanah pada kawasan mangrove menunjukkan bahwa tekstur tanah di perairan mangrove Desa Todowongi sesuai untuk kehidupan kepiting bakau. Kasry (1991) menyatakan bahwa kepiting bakau dapat hidup pada kondisi tanah liat, pasir, lumpur atau campuran ketiganya.

\subsection{Kualitas Air}

Parameter kualitas air yang diukur seperti suhu, salinitas dan $\mathrm{pH}$ air menunjukkan bahwa lokasi penelitian masih layak untuk kehidupan kepiting bakau. Kisaran suhu adalah $29-30{ }^{\circ} \mathrm{C}$, kisaran salinitas 30-31\%o, dan kisaran $\mathrm{pH}$ air 6,8 $-7,0$.

Suhu merupakan salah satu faktor lingkungan yang mempengaruhi kehidupan kepiting bakau (Kasry, 1991). Dari hasil penelitian menemukan bahwa suhu selama penelitian pada kawasan mangrove berkisar antara $29{ }^{\circ} \mathrm{C}-30{ }^{\circ} \mathrm{C}$ yang berarti bahwa suhu tersebut masih layak untuk kehidupan kepiting bakau. Sulistiono et al, (1992) menemukan kepiting bakau dapat hidup pada suhu $13{ }^{\circ} \mathrm{C}-40$ ${ }^{\circ} \mathrm{C}$ di perairan Segara Anakan; Mulya (2000) menemukan bahwa kepiting bakau pada kisaran suhu $28{ }^{\circ} \mathrm{C}-29,25{ }^{\circ} \mathrm{C}$ di Suaka Margasatwa Karang Gading, Sumatera Utara.

Salinitas pada kawasan mangrove berkisar antara 30\%-35\%. Kondisi tersebut masih dalam batas kelayakan kepiting bakau dan dapat hidup dengan baik, yaitu antara 15\%o-35\%o (Afrianto dan Liviawaty, 1992). Miswar (2000) dari hasil penelitiannya di Suaka Margasatwa Karang Gading, Sumatera Utara menemukan kepiting bakau pada kisaran salinitas 16,70 \% - 23,93\%.

Kisaran $\mathrm{pH}$ pada lokasi penelitian 6,8 7,0. Sindiarta dalam Siahainania (2000) menyatakan bahwa kisaran $\mathrm{pH}$ 6,50-7,50 dikategorikan perairan yang cukup baik sedangkan perairan dengan kisaran $\mathrm{pH} 7,50-8,50$ dikategorikan sangat baik. Dengan demikian kisaran nilai $\mathrm{pH}$ di lokasi penelitian masih layak untuk kehidupan kepiting bakau.

\subsection{Makanan Alami (Makrozoobentos)}

Berdasarkan hasil determinasi ditemukan 11 jenis makrozoobentos yaitu Turricula javana, Lepthiotoma indica, Cerithidae obtuse, Terebralia palustris, Terebralia sulcata, Nassarius dorsatus, Nerita squamulata, Lettorina scabra, Gafrarium pectinatum, Batissa violacea, Uca demani.

Arriola (1940) dalam Moosa et al., (1985) menyatakan bahwa selain pemakan bangkai 
(scavanger), kepiting bakau dewasa juga merupakan hewan pemakan bentos atau organisme yang bergerak lambat seperti bivalvia, kepiting kecil, kumang, cacing, gastropoda dan krustasea. Wibowo (1997) dari hasil penelitiannya di Pulau Tirang Malang, Segara Anakan menemukan 12 jenis makrozoobentos yaitu Littorina scabra, Cerithium bifasciatum, Telescopium telescopium, cantharus elegan, Nerita antiquata, Barbatia sp, Anadara sp, Tellina tennuis, S. Serrata, Panaeus merquensia, platinereis sp, dan Cirratulus sp. Persentase terbesar dari kelas gastropoda, (76,28\%), sedangkan krustasea, bivalvia dan polychaeta masing-masing $28 \%, 14 \%$ dan $2,75 \%$.

Hutan mangrove merupakan habitat alami kepiting bakau (Scylla spp). Hutan mangrove adalah wilayah pesisir yang memiliki kandungan bahan organik yang tinggi. Serosero (2005) dari hasil penelitiannya menemukan bahwa kandungan C-organik, N-total dan fosfat tinggi pada daerah hutan mangrove. Tipe sedimen pada daerah mangrove yang cenderung lebih halus menyebabkan kandungan Corganiknya tinggi karena kemampuannya mengakumulasi bahan organik ke dasar perairan. Nybakken (1992) menyatakan bahwa tekstur substrat berlumpur mempunyai kemampuan mengakumulasi bahan organik yang tinggi sehingga cukup tersedia makanan bagi organisme pantai. Tingginya nilai $\mathrm{N}$-total disebabkan karena daerah mangrove berdekatan dengan daerah pemukiaman sehingga aktivitas masyarakat seperti pembuangan sampah berdampak pada peningkatan N-total. Selain itu, kondisi substrat yang yang berlumpur menyebabkan terjadinya akumulasi bahan organik.

Kepadatan makrozoobentos yang ditemukan di lokasi penelitian disajikan pada gambar 2 berikut.

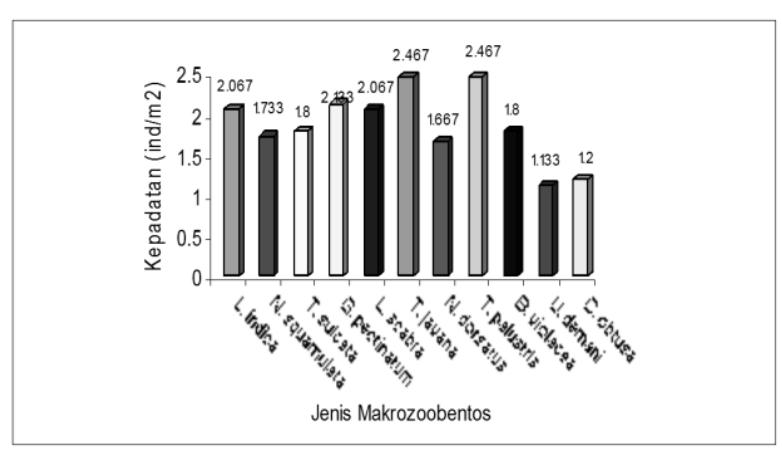

Gambar 2. Kepadatan makrozoobentos di perairan pantai Desa Todowongi
Berdasarkan hasil analisis kepadatan menunjukkan bahwa makrozoobentos jenis Turricula javana dan Tereblaria palustris memiliki kepadatan tertinggi yaitu 2,467 ind $/ \mathrm{m}^{2}$ ) dengan kepadatan total 20,533. Hal ini menunjukan bahwa kedua jenis tersebut memiliki kemampuan untuk beradaptasi dengan lingkungan tersebut. Nybakken (1992) menyatakan bahwa organisme yang memiliki kemampuan untuk menyesuaikan diri dengan lingkungannya akan memiliki kepadatan yang tinggi.

Hasil analisis keanekaragaman jenis makrozoobentos di perairan pantai Desa Todowongi disajikan pada gambar 3 berikut.

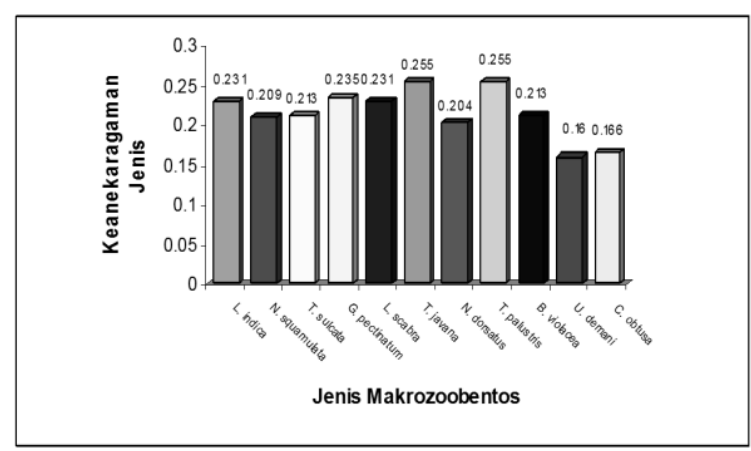

Gambar 3. Keanekaragaman jenis makrozoobentos di perairan pantai Desa Todowongi

Berdasarkan hasil analisis terlihat bahwa keanekaragaman jenis total makrozoobentos adalah 2,372 sehingga berdasarkan kriteria penggolongan keanekaragaman tergolong sedang karena nilai H' lebih besar dari satu dan kurang dari tiga koma tiga.

Indeks dominasi jenis makrozoobentos di perairan pantai Desa Todowongi dapat dilihat pada gambar berikut.

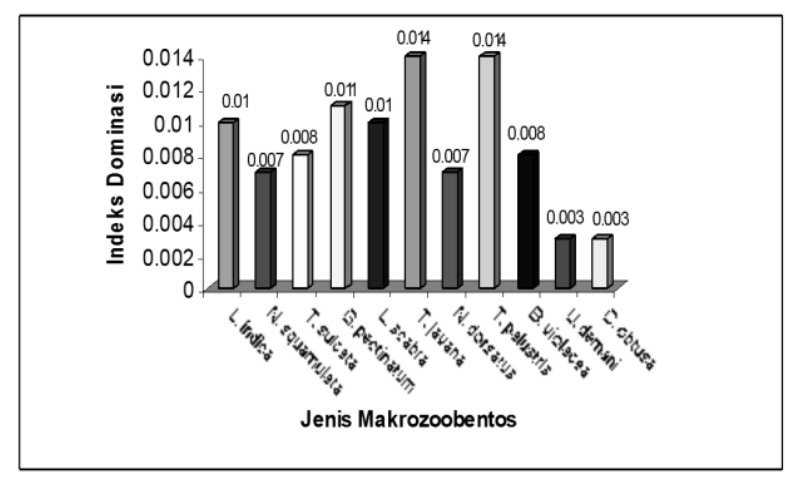

Gambar 4. Dominasi makrozoobentos di perairan pantai Desa Todowongi 
Dari hasil analisis tersebut menunjukkan bahwa tidak ada jenis makrozoobentos yang mendominasi di lokasi penelitian. Hal ini disebabkan karena nilai indeks dominasinya mendekati nol.

\section{KESIMPULAN DAN SARAN}

\subsection{Kesimpulan}

1. Karakteristik habitat berupa tekstur substrat yaitu lempung berpasir

2. Parameter lingkungan (suhu, salinitas, $\mathrm{pH}$ air) berada pada kondisi yang layak bagi kehidupan kepiting bakau.
3. Makrozoobentos yang ditemukan terdiri atas 11 dengan nilai kepadatan tertinggi dari jenis Turricula javana dan Tereblaria palustris memiliki kepadatan tertinggi yaitu 2,467 ind $/ \mathrm{m}^{2}$ ) dengan kepadatan total 20,533, keanekargaman jenisnya tergolong rendah dan tidak ada jenis yang mendominasi.

\subsection{Saran}

Perlu dilakukan penelitian tentang pengaruh habitat dan lingkungan terhadap perkembangan kepiting bakau untuk kegiatan budidaya.

\section{DAFTAR PUSTAKA}

Abbot, RT. 1989. American Seashells. The marine Mollusca of the Atlantic and Pasific Coasts of North America. Van Nostrand Reinhold Company. New York.

Afrianto, E dan E, Liviawaty. 1992. Pemeliharaan Kepiting. Kanisius, Yogyakarta

Dharma, 1988. Siput dan Kerang Indonesia. Sarana Graha Indonesia. Jakarta

Effendi H. 2003. Telaah Kualitas Air Bagi Pengelolaan Sumberdaya dan Lingkungan Perairan. Penerbit PT. Kanisiun. Yogyakarta.

Hanafiah, K. Ali. 2005. Dasar-Dasar Ilmu Tanah. Pustaka Utama. Jakarta.

Kasry A. 1991. Budidaya Kepiting Bakau dan Biologi Ringkas. Bhratara. Jakarta.

Ludwig E.J and Reynolds. 1988. Statistical Ecology A Primer in Methods and Computing. John Wiley and Sons. New York.

Mulya, M.B. 2000. Kelimpahan dan Distribusi Kepiting Bakau (Scylla spp) serta Keterkaitannya Dengan Karakteristik Biofisik hutan mangrove di suaka Margasatwa Karang Gading dan Langkat Timur Laut Propinsi Sumatera utara. Tesis. Program pasca sarjana IPB.

Moosa MK, 1. Aswandy A. Kasry. 1985. Kepiting Bakau, Scylla serrata (Forskal) di Perairan Indonesia. LON-LIPI, Jakarta.

Nybakken, J. W. 1992. Biologi Laut Suatu Pendekatan Ekologis. PT Gramedia. Jakarta

Odum, E.P. 1996. Dasar-Dasar Ekologi. Terjemahan oleh Samingan dan B. Srigadi. Universitas Gajah Mada Press. Yogyakarta.

Siahaenenia, L. 2000. Distribusi Kelimpahan Kepiting Bakau (Scylla serrata, Scylla oceanica dan Scylla tranquebarica) dan Hubungannya dengan Karakteristik habitat pada Kawasan hutan mangrove Teluk Pelita Jaya, Seram Barat-Maluku. Tesis. Program Pasca Sarjana.

Sulistiono S Watanabe, S.Tsuchida. 1992. Biology and Fisheries of Crabs in Segara Anakan Lagoon (tidak dipublikikan). Makalah Hasil Penelitian Bersama Antara Fakultas Perikanan IPB dengan Departemen of Aquatic Biosciences, Tokyo University of Fisheries.

Serosero, R. 2005. Karakter Morfometrik Kepiting Bakau (Scylla serrata, Scylla paramamosain, Scylla olivacea) Di Perairan Pantai Desa Mayangan Kab. Subang Jawa Barat. Jurnal Sorihi, Vol 1, No 5, Juli 2006. Fakultas Perikanan dan Ilmu Kelautan Universitas Khairun Ternate.

Wattimury, J.F. Martha. 2006. Potensi dan Pemanfaatan Ekosistem Mangrove di Pesisir Teluk Ambon. Tesis. Program Pasca Sarjana UNSTRAT. Manado. 